\title{
11
}

\section{THE ELECTION IN THE STATES, TERRITORIES AND REGIONS}

Nick Economou, Zareh Ghazarian, Narelle Miragliotta, Will Sanders, Rodney Smith, John Warhurst and Paul Williams

In this chapter, we contextualise the regional variation in the 2019 election results by focusing on some of the local factors that influenced the campaign and the outcomes in each of the Australian States and Territories. While the States and Territories appear to have some influence on federal election outcomes, the reasons for this remain unclear (Martinez i Coma and Smith 2018). Investigating the diversity of election campaign issues, events and styles across Australia, we examine, where relevant, previous State and Territory election results, economic conditions, specific policy promises and campaign visits from the major party leaders, and analyse notable regional variations within each jurisdiction. A number of competitive 'battleground' seats are highlighted, which are seen as important for the overall outcome of the election, drawing significant resources from the major parties and attracting substantial media attention during the campaign. 


\section{New South Wales}

\section{By Rodney Smith}

Apart from the fact that it provided around one-third of the 151 members of the House of Representatives, New South Wales was particularly important in 2019 because it contained a large proportion of marginal seats. The 2016 federal election left the major parties evenly balanced in New South Wales, with Labor holding 24 seats against the Coalition's 23 seats. By the 2019 federal election, the Liberal Party had narrowly lost the seat of Wentworth to the Independent Kerryn Phelps in a by-election caused by Malcolm Turnbull's resignation from parliament. Based on the 2016 results, swings to Labor of 2.5 per cent would take four NSW seats from the Coalition (Gilmore, Robertson, Banks and Page). On the other hand, if the Coalition managed swings towards it of 2.5 per cent, Labor would lose two NSW seats (Lindsay and Macquarie). Finally, a 1.1 per cent swing to the Liberals would see them regain Wentworth. Thus, New South Wales contained seven of the 23 marginal seats most likely to be critical to the 2019 outcome-more than any State except Queensland, which had eight.

\section{Contextual factors}

Two factors that might be important in explaining the results of the election are State economic conditions and State politics. In 2019, neither of these suggested that Labor would make significant gains against the Coalition in New South Wales.

For 18 months after the July 2016 federal election, the NSW economy performed strongly relative to the other States; however, it began to show some signs of weakening prior to the 2019 federal election. The annual percentage increase in gross State product to July 2018 in New South Wales was the lowest of all States and Territories, at 1 per cent (ABS 2018). The economic growth that did occur in New South Wales was uneven. The construction sector, driven partly by the NSW Government's heavy investment in public infrastructure projects (NSW 2018), contributed very visibly to the State's economic growth. However, the NSW agricultural sector contracted significantly (ABS 2018). To the extent that swinging voters judge governments retrospectively on their economic performance (Fiorina 1981), rather than voting on probable future economic conditions, the economic position of New South Wales gave them little cause to punish the federal Coalition. 
The vagaries of election cycles produced the unusual circumstance of both national and NSW Coalition governments attempting to win third terms in the first half of 2019. The NSW fixed-term election was set for 23 March. Ultimately, the Coalition was returned to government in New South Wales with a slim majority, winning 48 of the 93 seats in the NSW Legislative Assembly. It recorded a first-preference legislative assembly vote of 41.6 per cent-down 4.1 per cent on the 2015 result. Labor barely improved its position, winning 33.3 per cent of the firstpreference votes-down 0.8 per cent from 2015-and a notional two-party-preferred swing of 2.3 per cent across the State.

What were the implications of this result for the federal contest? Labor's failure to make large gains at State level suggested the Coalition might be able to hold on to its federal NSW seats. Labor did not achieve first-preference or two-party-preferred swings of real magnitude in any NSW region except northern Sydney, where the Liberals could be expected to retain their seats easily. The NSW win undoubtedly boosted Coalition morale, particularly within the Liberal Party. It paved the way for the Coalition to make infrastructure commitments during the federal campaign that would receive wholehearted support from the newly elected State Liberal Premier. Moreover, the Coalition's NSW campaign theme, that Labor would ruin the State's strong budgetary position, suggested the way the Coalition might campaign effectively against Labor at the federal poll.

\section{The campaign in New South Wales}

As in 2016, in 2019 the major party leaders visited NSW electorates for policy announcements more often than they did electorates in the other States and Territories (see Table 11.1; and Martinez i Coma and Smith 2018: 220). The difference between 2016 and 2019 is that in 2016 Bill Shorten made as many visits to NSW electorates as did his Liberal opponent, Malcolm Turnbull, while in 2019, Shorten was much less visible in New South Wales than Scott Morrison. Morrison's first visit of the campaign, on 11 April, was to the marginal Labor seat of Lindsay, in Sydney's west, while Shorten began his campaign in Deakin (see 'Victoria', below) - a relatively safe Liberal seat in Melbourne's east. These starting points could simply have been due to home State convenience (Morrison being from Sydney and Shorten from Melbourne); however, Shorten's relative lack of attention to New South Wales in 
2019 appears to have been strategic. Shorten's last major campaign event was a meeting at Blacktown Town Hall in Sydney's west-a venue made iconic by Gough Whitlam's 'It's Time' campaign speech in 1972 (Chan 2019). Nonetheless, Table 11.1 shows that Morrison campaigned more frequently than Shorten in New South Wales, while Shorten focused more of his campaigning on Queensland, where polling suggested Labor might pick up more seats (see below). The two leaders gave roughly the same amounts of attention to the other States and Territories.

Table 11.1 Leaders' electorate visits by State and Territory

\begin{tabular}{|l|r|r|r|c|}
\hline & Morrison & Shorten & McCormack & Total \\
\hline NSW & 23 & 14 & 12 & $49(37 \mathrm{M}+\mathrm{S})$ \\
\hline Qld & 11 & 16 & 7 & $34(27 \mathrm{M}+\mathrm{S})$ \\
\hline Vic. & 15 & 16 & 4 & $35(31 \mathrm{M}+\mathrm{S})$ \\
\hline WA & 10 & 8 & 0 & $18(18 \mathrm{M}+\mathrm{S})$ \\
\hline SA & 5 & 5 & 0 & $10(10 \mathrm{M}+\mathrm{S})$ \\
\hline Tas. & 9 & 7 & 3 & $19(16 \mathrm{M}+\mathrm{S})$ \\
\hline ACT & 0 & 0 & 0 & $0(0 \mathrm{M}+\mathrm{S})$ \\
\hline NT & 2 & 2 & 0 & $4(4 \mathrm{M}+\mathrm{S})$ \\
\hline Totals & $\mathbf{7 5}$ & $\mathbf{6 8}$ & $\mathbf{2 7}$ & $\mathbf{1 7 0}(\mathbf{1 4 3} \mathbf{~ M + ~ S )}$ \\
\hline
\end{tabular}

Source: Calculated from Worthington (2019).

Despite frequent news media commentary to the effect that Western Sydney was a key 'battleground' in the election, the leaders spent relatively little time there. Morrison made six visits to Western Sydney electorates, three of them to Lindsay. Shorten made just two visits to Western Sydney electorates (Lindsay and Greenway). Most electorates in Western Sydney went unvisited by either leader. Both leaders made more visits to inner Sydney electorates, particularly Reid, which each of them visited for five events (see Table 11.2).

The only electorates outside Sydney visited by both leaders were the marginal seats of Gilmore on the NSW South Coast and Robertson on the Central Coast. As might have been expected, National Party Leader Michael McCormack focused his attention on coastal and inland rural seats, including his own seat of Riverina. 
Table 11.2 Leaders' electorate visits by NSW region

\begin{tabular}{|l|r|r|r|r|r|r|}
\hline & Morrison & Shorten & McCormack & $\begin{array}{c}\text { Unvisited } \\
\text { electorates* }\end{array}$ & $\begin{array}{c}\text { Contested } \\
\text { electorates* }^{* *}\end{array}$ & Total \\
\hline $\begin{array}{l}\text { Inner } \\
\text { Sydney }\end{array}$ & 8 & 6 & 0 & 1 & 2 & 5 \\
\hline $\begin{array}{l}\text { Northern } \\
\text { Sydney }\end{array}$ & 0 & 1 & 0 & 4 & 0 & 5 \\
\hline $\begin{array}{l}\text { Southern } \\
\text { Sydney }\end{array}$ & 2 & 0 & 0 & 2 & 0 & 4 \\
\hline $\begin{array}{l}\text { Western } \\
\text { Sydney }\end{array}$ & 6 & 2 & 0 & 8 & 1 & 12 \\
\hline $\begin{array}{l}\text { Central } \\
\text { Coast }\end{array}$ & 2 & 3 & 0 & 0 & 1 & 2 \\
\hline $\begin{array}{l}\text { Hunter/ } \\
\text { Illawarra }\end{array}$ & 1 & 0 & 0 & 5 & 0 & 6 \\
\hline $\begin{array}{l}\text { Coastal } \\
\text { rural }\end{array}$ & 3 & 2 & 5 & 3 & 1 & 6 \\
\hline Inland rural & 1 & 0 & 7 & 4 & 0 & 7 \\
\hline Total & $\mathbf{2 3}$ & $\mathbf{1 4}$ & $\mathbf{1 2}$ & $\mathbf{2 7}$ & $\mathbf{5}$ & $\mathbf{4 7}$ \\
\hline
\end{tabular}

* Electorates not visited by Labor or Coalition leaders during the campaign.

** Electorates that both Labor and Coalition leaders visited to make announcements and campaign.

Source: Calculated from Worthington (2019).

In 2019, the major parties seemed to do less to target particular regions with policy packages than they had in 2016 (Martinez i Coma and Smith 2018: 221-22). The Liberal Party did package policies for four specific regions, including one addressed to Western Sydney. ${ }^{1}$ Labor did not produce policy packages specifically for any NSW regions but included State-by-State breakdowns of some of its funding promises - for example, on education and infrastructure (ALP 2019a, 2019b). On key policies affecting specific regions, such as the development of the Western Sydney airport, the major parties' promises were quite similar (Liberal Party of Australia 2019b; ALP 2019b). Most of the parties' policies were directed generally at the national electorate. This was also true of 2016; however, in 2019, the parties seemed to expect voters to do more work to find out how policies might affect their own areas.

1 The other regional packages covered Tasmania, the Northern Territory and Central Queensland (Liberal Party of Australia 2019a). 


\section{Regional results}

The overall results in New South Wales showed little change from either the 2016 federal election results or the March 2019 NSW State election. In two-party-preferred terms, the Coalition only lost votes to Labor in inner and northern Sydney-both areas where the Liberal Party could afford to lose votes. In Western Sydney, the Liberal Party gained ground in both its average first-preference vote (up 3 per cent) and against Labor in two-party-preferred terms (up 2.7 per cent). The 47.1 per cent average two-party-preferred Liberal vote in Western Sydney was high enough to undermine the still common idea that the diverse region of Western Sydney is a 'Labor heartland'. Outside Sydney, there were relatively few changes in votes. Overall, very few seats changed hands in New South Wales. Labor won Gilmore from the Liberals with a swing of 3.3 per cent but suffered swings against it in all the other marginal NSW seats, including Lindsay, which it lost. In both Gilmore and Lindsay, the incumbent MPs did not recontest their seats in controversial circumstances. This provides part of the explanation for the results in these seats; however, Labor's general failure to make up ground in marginal NSW seats was the larger and more important factor at work.

\section{Victoria}

\section{By Nick Economou and Zareh Ghazarian}

Since the 1993 federal election, Victoria has been a State in which the ALP has been the party preferred by the majority of voters. Given the persistent two-party majorities for Labor and notwithstanding the two-party swings that occur between elections, it is rare for anything other than a small number of ultra-marginal seats to change hands between the major parties in Victoria. The 2019 contest conforms with this dominant pattern.

\section{Contextual factors}

The expectation that the Liberals and Nationals were in some trouble in Victoria owed something to the State election held in November 2018. This election resulted in a landslide Labor victory in which there were significant swings to Labor in previously strong Liberal-voting districts in Melbourne's eastern suburbs and in the southeastern suburban 
growth corridor. The assumption was that the State election result was driven in no small way by voter response to events in federal politics in which Malcolm Turnbull had lost the prime ministership as a result of manoeuvring by ultra-conservative Liberals such as Michael Sukkar, the sitting Member for Deakin. Further, the Liberal members for Chisholm and Higgins, Julia Banks and Kelly O'Dwyer, had resigned from the Liberal Party citing a culture of male bullying. This, in turn, had flushed out Liberal Party State President Michael Kroger, who had to defend his party's reputation at the very time he was also involved in a major intraparty battle with the Cormack Foundation in a bid to gain access to campaign funds.

\section{The campaign in Victoria}

Labor's interest in the State was inevitable given that Opposition leader Bill Shorten held a Victorian seat (the western suburban division of Maribyrnong). Shorten was clearly of a mind to replicate the approach of his State colleague, Premier Daniel Andrews, as he travelled across metropolitan Melbourne promising federal support for a slew of transport infrastructure projects, the most ambitious of which was a proposal to construct a massive underground rail loop traversing the middle suburbs. Not to be outdone, Prime Minister Scott Morrison travelled to Corangamite to promise federal support to build a very fast rail connection between Geelong and Melbourne. Labor tried to up the ante with a promise to pour taxpayer funds into the Australian Football League stadium at Kardinia Park, also in Geelong. Back in Melbourne, Morrison committed federal funds to the construction of the infamous East-West Link-the proposed freeway to be tunnelled under the Greens-voting inner suburb of Carlton that the State Labor Government had refused to consider building.

\section{Regional results}

At the beginning of the election and at its conclusion, Labor held 21 seats in Victoria, the Liberals 12 seats, the Nationals three seats, the Greens one and there was one Independent. Save for a few new faces due to take their place on the back benches of the House of Representatives, nothing much changed. 
Of course, the fact that there was no substantive change to the 2016 result was in fact the important outcome in the context of the general election result. Predictions of a Labor victory in the national contest were based on an assumption of a shift of Liberal seats to Labor occurring in a State such as Victoria. The expectation of such an outcome was driven by two electoral events preceding the 2019 national vote. First, Victoria was the State in which there was strongest support for same-sex marriage, with 65 per cent of Victorians voting 'yes' in the postal survey held in 2017. This suggested the State would reject the Coalition at the national level, especially as it was led by prominent socially conservative figures who had toppled the progressive Turnbull. Second, federal Labor's hopes of a strong performance in Victoria were buoyed by the significant realignment of voter support from Liberal to Labor in previously strong Liberal seats in the 2018 State election.

The fact that the expected Labor swing did not eventuate suggests either the 2018 State election was a ringing endorsement of the State Labor Government and its premier or something happened in between the State and federal elections to prevent the expected federal realignment occurring. The results from the 2019 federal contest do not give any clear insights as to what happened between the two elections other than to show that, at least in terms of the primary vote, it was the UAP that received the biggest swing, after which Independents and Labor received the next best swings. A review of the two-party swings by electoral division does not give much insight either, other than to highlight that, while there were swings to Labor in some of the Liberal Party's most marginal seats, they were nowhere near enough to result in a transfer of seats. Expectations of non-major party success were also unmet and the one incumbent Independent had to withstand a 4 per cent swing against her.

The reality of the Victorian result was that it was more akin to a confirming election than a government-changing election in that the result in 2019 was almost the same as it had been in 2016, notwithstanding all that had happened in the national political debate over that three-year cycle. The swing to Labor in Victoria in 2019 was negligible and certainly not of sufficient dimensions to result in a transfer of seats. All the other predictions of non-major party success by Greens and/or Independents also proved to be wrong. In accounting for the Victorian result, it is worth remembering that the 2019 outcome-in which Labor won the Statewide two-party vote but few, if any, seats changed hands-follows a longstanding pattern in Australian electoral politics. 


\section{Queensland}

\section{By Paul Williams}

The unexpected result of the 2019 federal election campaign in Queensland, in defiance of reputable public opinion polls, marks it out as one of historical significance. News media narratives once again framed Queensland as a key battleground State but no published poll correctly forecast Labor's 26.7 per cent primary vote-the federal party's worst result in Queensland since 1901 and equivalent to the decimation of Anna Bligh's Labor Government in 2012.

The 2019 election supported the 'Queensland is different' thesis (Murphy 1978; McQueen 1979; Charlton 1983; Williams 2009, 2011). As a 'frontier' State-where agriculture, pastoralism and especially mining make up the core of economic activity and forge a political culture far removed from the 'Sydney-Melbourne-Canberra triangle'regional Queensland shares characteristics with regional Tasmania, Western Australia, the Northern Territory and parts of New South Wales (for example, the seat of Hunter). But Queensland ultimately remains different given its status as Australia's most decentralised State, where more voters live outside the capital city than within it. Queensland comprises six regions, each exercising distinct electoral behaviours: Brisbane, Brisbane fringe, Gold Coast, Sunshine Coast, eastern provincial and western rural (Williams 2018b). Understanding this diversity, and how minor populist parties (and parts of the LNP) exploit those differences, is therefore essential to unpacking Queensland's role in the 2019 federal election.

Queensland voters-especially regional voters who have long bristled at post-material environmentalist and human rights policy agendas supplanting economic priorities-were primed for a conservative backlash long before the 2019 campaign began. From issues that much of regional Queensland found antithetical or irrelevant—of which anger at strict controls on tree-clearing and lower than average support for samesex marriage are obvious manifestations - to major party leadership that failed to resonate with regional Australia, the 45th Parliament proved fertile ground for new conservative and populist leadership to take root in Queensland. More specifically, the seeds of the LNP's Queensland surge were sown overwhelmingly by two factors: Scott Morrison's accessible, pragmatic and occasionally populist leadership style, which contrasted strongly with Bill Shorten's apparently aloof and mistrusted persona; 
and material economic concerns - of which the Adani coalmine and its promise of regional employment were merely one element-that saw voters reject both environmental concerns and Labor's arguably complicated and poorly defended tax policy in favour of what appeared to be the Coalition's pledge to keep taxes lower.

\section{Contextual factors}

At the 2017 State election, a relatively popular State Labor Government under Annastacia Palaszczuk increased its seat share. The LNP, by contrast, suffered a 7.6 per cent primary swing and won just 33.7 per cent of the primary vote (Williams 2018a). However, the Queensland economy throughout the 45th Parliament continued to suffer a post-mining slump that saw State unemployment hover around 6 per cent-higher than the national average-with regional unemployment around twice that, and youth unemployment in seats such as Herbert approaching 20 per cent (QGSO 2019; Brown 2019). Moreover, the collapse of Clive Palmer's Queensland Nickel in 2016-with $\$ 70$ million long owed to workers in and around Townsville - made the mining downturn particularly piquant for north Queensland. Add the fact that wage growth had barely kept pace with inflation during a 'per capita recession' (Commins 2019) and regional Queensland promised a perfect storm for a regional blue-collar backlash against a federal Coalition that spruiked a buoyant national economy but delivered little household prosperity.

Despite the Adani coalmine anecdotally playing a pivotal role in Labor's defeat in regional Queensland, voter salience regarding this thorny issue did not initially appear high. Opinion polls during the 2017 State campaign indicated, for example, that just 17 per cent of voters rated the issue as important (Marszalek 2017; Williams 2018a). And when voters did show interest, public opinion appeared to be turning against the mine. Indeed, Palaszczuk enjoyed a mid-campaign fillip when she pledged to veto any federal public money being allocated to Adani for infrastructure. By early 2019, a YouGov-Galaxy poll found 51 per cent of Queenslanders supported coalmining generally, but just 37 per cent endorsed the Adani project specifically (Killoran 2019). In that sense, the Adani issue appeared to be totemic: while only a minority of Queenslanders were passionate about the Adani project specifically-which was not unexpected given publicised threats to groundwater, the Great Barrier Reef and the blackthroated finch—regional voters saw the project as a lifeline to community 
revival. The fact Queenslanders rated material economic interests more highly than the environment - the reverse of the Australian averageis evidenced in Table 11.3.

Table 11.3 Critical issues for voters, Queensland and Australia, 2019 (per cent)

\begin{tabular}{|l|r|r|}
\hline Issue & Queensland & Australia \\
\hline Economy & 27 & 23 \\
\hline Environment & 24 & 29 \\
\hline Superannuation/pensions & 8 & 8 \\
\hline
\end{tabular}

Note: Per cent of respondents who identified these issues as most important to them in the 2019 election.

Source: Hanrahan (2019).

Notwithstanding these data, Adani's polarising effect clearly shaped voting intentions in all 30 Queensland seats (and in many outside Queensland), with Adani enjoying its strongest salience in the five seats closest to the mine's site in the Galilee Basin: Capricornia (the mine's location), Herbert, Dawson, Flynn and Maranoa. In Flynn - held by the LNP by just 1 percentage point-a YouGov-Galaxy poll found 55 per cent of voters (including one-third of Labor voters) rated the Adani mine as 'vital' for the future of central Queensland (Viellaris 2019).

\section{The campaign in Queensland}

Scott Morrison spent one-third of his campaign in Queensland-mostly in the regions-which was more than any other State except New South Wales. On successive tours, the Prime Minister pledged road infrastructure and repeated his mantra that Labor's $\$ 387$ billion tax plan-including a so-called retirement tax and allegations of 'death duties' - would cripple Australia (Hewett 2019). Consequently, a YouGov-Galaxy poll found 59 per cent of all Queensland voters, and 27 per cent of Labor voters, preferred the Coalition's tax plan, compared with just 26 per cent of all Queensland voters who supported Labor's (Killoran and Smethurst 2019). In total, Morrison-including in a late blitz during the campaign's final week-visited the seats of Herbert, Flynn and Brisbane three times, Capricornia twice and Forde, Petrie, Longman and Leichhardt once each.

Aware of Queensland's capacity to make or break his campaign, Shorten also focused heavily on Queensland, and launched his Queensland campaign in Brisbane on 5 May. Curiously, the Opposition leader waited until the final 
week to visit Labor's most marginal seat of Herbert. Nonetheless, Shorten continued to campaign on his ability to deliver fairness while governing with unity and stability, but poorly defended policies on tax and Adani plagued him. While supporting mining generally, for example, Shorten refused to sign a Construction, Forestry, Maritime, Mining and Energy Union (CFMMEU) pledge to guarantee the Adani project and he maintained his right to review any Queensland Government approval (McKay 2019).

The Greens' campaign produced an unintended effect on regional Queenslanders contemplating a Labor vote. The 'Stop Adani' convoywhich travelled for 18 days under the tutelage of former Greens leader Bob Brown from Tasmania to Brisbane and then to Clermont, the heart of the Adani site, before moving to Canberra-raised the ire of regional Queenslanders in the five 'Adani' seats. Vilified as southern 'blow-ins', the Greens-led convoy galvanised local resentment toward 'outsiders', allowed a vacillating Labor Party to be conflated with Greens policies and ultimately fuelled Morrison's pleas for locals to reject a progressive policy agenda. Once again, even those in regional Queensland ambivalent about the mine would have seen Adani's approval as a totemic rejection of 'outsider' interference.

\section{Regional results}

While acknowledging the limitations of applying regional analysis to geographically large federal electorates that inevitably overlap criterion borders, Table 11.4 reveals Labor lost disproportionate support across the Brisbane fringe and in provincial towns along the eastern seaboard-each long considered blue-collar Labor heartlands (Williams 2018a, 2018b). Labor can take some comfort from the fact its losses were more moderate across Brisbane's middle-class suburbs. While swings against Labor were moderate also on the Gold and Sunshine coasts and in rural Queensland, the fact these moved from already low Labor bases provided the party no succour. The LNP, conversely, hardly improved its position in suburban Brisbane or rural Queensland, it declined in its Gold Coast heartland and made only modest gains in the Brisbane fringe. None of these results allows the LNP to rest on its laurels. Dramatically improved results, at Labor's expense, for PHON in all regions (especially the Brisbane fringe but not western rural) and for the UAP in all regions except Brisbane city, delivered gains to the LNP via preferences. Interestingly, PHON and the UAP performed better in Sunshine Coast seats than in Gold Coast seats. 
Table 11.4 Queensland primary vote and swing, by region, 2019 federal election (per cent)

\begin{tabular}{|c|c|c|c|c|c|c|}
\hline Region (no. of seats) & $\begin{array}{l}\text { Labor } \\
\text { (swing) }\end{array}$ & $\begin{array}{c}\text { LNP } \\
\text { (swing) }\end{array}$ & $\begin{array}{r}\text { PHON } \\
\text { (swing) }\end{array}$ & $\begin{array}{l}\text { Greens } \\
\text { (swing) }\end{array}$ & $\begin{array}{c}\text { UAP } \\
\text { (swing) }\end{array}$ & $\begin{array}{c}\text { Other } \\
\text { (swing) }\end{array}$ \\
\hline Brisbane (6) & $\begin{array}{r}30.3 \\
(-2.6)\end{array}$ & $\begin{array}{r}44.8 \\
(+0.4)\end{array}$ & $\begin{array}{r}3.3 \\
(+3.3)\end{array}$ & $\begin{array}{r}18.2 \\
(+3.2)\end{array}$ & $\begin{array}{r}1.9 \\
(+1.9)\end{array}$ & $\begin{array}{r}1.5 \\
(-6.2)\end{array}$ \\
\hline Brisbane fringe (8) & $\begin{array}{r}33.5 \\
(-5.9) \\
\end{array}$ & $\begin{array}{r}40.0 \\
(+1.3) \\
\end{array}$ & $\begin{array}{r}9.6 \\
(+5.5) \\
\end{array}$ & $\begin{array}{r}9.4 \\
(+2.1) \\
\end{array}$ & $\begin{array}{r}3.3 \\
(+3.3) \\
\end{array}$ & $\begin{array}{r}4.2 \\
(-6.3) \\
\end{array}$ \\
\hline Gold Coast (3) & $\begin{array}{r}23.3 \\
(-2.7) \\
\end{array}$ & $\begin{array}{r}49.5 \\
(-4.2) \\
\end{array}$ & $\begin{array}{r}7.0 \\
(+3.0) \\
\end{array}$ & $\begin{array}{r}9.9 \\
(+0.6) \\
\end{array}$ & $\begin{array}{r}4.0 \\
(+4.0) \\
\end{array}$ & $\begin{array}{r}6.3 \\
(-0.7) \\
\end{array}$ \\
\hline Sunshine Coast (2) & $\begin{array}{r}21.9 \\
(-1.6) \\
\end{array}$ & $\begin{array}{r}49.8 \\
(+1.5) \\
\end{array}$ & $\begin{array}{r}8.3 \\
(+3.2) \\
\end{array}$ & $\begin{array}{l}12.5 \\
(0.0) \\
\end{array}$ & $\begin{array}{r}3.3 \\
(+3.3) \\
\end{array}$ & $\begin{array}{r}4.2 \\
(-6.4) \\
\end{array}$ \\
\hline Eastern provincial (7) & $\begin{array}{r}24.5 \\
(-5.8)\end{array}$ & $\begin{array}{r}41.3 \\
(-0.3)\end{array}$ & $\begin{array}{r}13.2 \\
(+2.8)\end{array}$ & $\begin{array}{r}6.2 \\
(+0.6)\end{array}$ & $\begin{array}{r}4.4 \\
(+4.4)\end{array}$ & $\begin{array}{r}10.4 \\
(-1.7)\end{array}$ \\
\hline Western rural (4) & $\begin{array}{r}17.5 \\
(-3.2)\end{array}$ & $\begin{array}{r}45.5 \\
(+1.0)\end{array}$ & $\begin{array}{r}10.4 \\
(+0.7)\end{array}$ & $\begin{array}{r}6.0 \\
(+0.4)\end{array}$ & $\begin{array}{r}4.8 \\
(+4.8)\end{array}$ & $\begin{array}{r}15.8 \\
(-3.7)\end{array}$ \\
\hline
\end{tabular}

Note: Divisions are Brisbane (Brisbane, Bonner, Griffith, Lilley, Moreton, Ryan); Brisbane fringe (Blair, Bowman, Dickson, Forde, Longman, Oxley, Petrie, Rankin); Gold Coast (Fadden, McPherson, Moncrieff); Sunshine Coast (Fairfax, Fisher); eastern provincial (Capricornia, Dawson, Flynn, Herbert, Hinkler, Leichhardt, Wide Bay); western rural (Groom, Kennedy, Maranoa, Wright).

Source: Author's calculations from AEC (2019a).

Table 11.5 Comparing 'Adani' seat and Queensland results, primary vote and swing, 2019 federal election (per cent)

\begin{tabular}{|l|r|r|r|r|}
\hline Party & $\begin{array}{c}\text { 'Adani' seat } \\
\text { primary (swing) }\end{array}$ & $\begin{array}{c}\text { 'Adani' seat } \\
\text { TPP (swing) }\end{array}$ & $\begin{array}{c}\text { Queensland } \\
\text { primary (swing) }\end{array}$ & $\begin{array}{c}\text { Queensland } \\
\text { TPP (swing) }\end{array}$ \\
\hline LNP & 42.8 & $\begin{array}{r}63.9 \\
(+9.4)\end{array}$ & $\begin{array}{r}43.7 \\
(+0.5)\end{array}$ & $\begin{array}{r}57.7 \\
(+3.6)\end{array}$ \\
\hline ALP & $22.0)$ & 36.1 & 26.7 & 42.3 \\
& $(-7.8)$ & $(-9.4)$ & $(-4.2)$ & $(-3.6)$ \\
\hline PHON & 15.1 & - & 8.9 & - \\
& $(+8.8)$ & & $(+3.3)$ & - \\
\hline Greens & 4.6 & - & 10.3 & - \\
& $(+0.8)$ & $-1.5)$ & - \\
\hline UAP & 4.4 & & 3.5 & \\
\hline Other & $(+4.4)$ & - & $6.5)$ & \\
& 10.3 & & $(-4.6)$ & \\
\hline
\end{tabular}

- not applicable

Note: The five 'Adani' seats are Capricornia, Herbert, Dawson, Flynn and Maranoa.

Source: Author's calculations from AEC (2019a). 
Table 11.5 indicates that while the five Adani seats produced primary swings to the LNP only slightly larger than the Queensland mean, those same seats saw huge two-party-preferred swings-via populist right preferences-almost three times the Queensland average. The table also reveals a significant spike in PHON support-again, largely from an increased field - and levels of UAP support higher than the Queensland average. Overall, these data, including the modest increase in the Greens' vote, support the claim that Adani was a highly salient, indeed polarising, issue in central Queensland.

\section{Western Australia}

\section{By Narelle Miragliotta}

Western Australia was one of three key battleground States in 2019. This time around, Labor had grounds to believe that the State, which had long eluded the party, might finally deliver for it. At the 2016 federal election, Labor had enjoyed a modest but notable improvement in its primary vote (an increase of 3.7 per cent), signifying that a possible correction was occurring. And, at the March 2017 State election, the State Labor Party, led by Mark McGowan, achieved a swing of 9.1 per cent in its primary vote, claiming government.

Labor entered this contest with hopes of retaining its five existing electorates and also securing five additional seats: Hasluck (held by Ken Wyatt, then Minister for Senior Australians and Aged Care and Minister for Indigenous Health), Swan, Stirling (in which the incumbent, Michael Keane, resigned), Pearce (held by Attorney-General, Christian Porter) and Canning. Of these seats, $\$ 500,000$ was spent on the campaign to win the inner metropolitan seat of Swan (Scarr 2019b). Labor's candidate, Hannah Beazley, was considered a strong prospect to secure the seat formerly held by her father, Kim Beazley, between 1980 and 1996.

\section{The campaign in Western Australia}

The importance of Western Australia to a Labor victory was reflected in the increased campaign visits Bill Shorten made to the State (12 per cent, up from 9 per cent in 2016), the promise to hold a historic summit of business and unions in Western Australia if elected (Lewis 2019: 9) 
and a $\$ 105$ million pledge towards defence industry infrastructure for West Australian shipyards. Labor also sought to leverage the popularity of the State Labor Premier and the strong economic credentials of the State government, which, against expectations, delivered a $\$ 553$ million surplus in its May Budget (Hondros et al. 2019).

While the underlying conditions for Labor in the State were encouraging, the Liberals were in full defensive mode. Scott Morrison visited Western Australia regularly throughout the campaign and was quick to flatter West Australian voters with his declaration that he would live in the west if he did not already call New South Wales home (Scarr 2019a). The Morrison Government was also able to take credit for increasing Western Australia's share of the goods and services tax (GST) and placing a floor under future GST allocations-long a sore point for the State (Laschon 2018). Moreover, the Liberals came to the State bearing various infrastructure projects totalling $\$ 1.4$ billion, including a $\$ 349$ million upgrade to the Tonkin Highway that would benefit voters in four of the party's marginal electorates, including Labor's most marginal seat of Cowan (Blaxendale and Varga 2019: 6).

There were also indications that some of Labor's policies might frustrate its much-hoped-for recovery. Polling of voters conducted in four marginal seats for the Liberals by MediaReach suggested that voters in these electorates believed Labor's proposed changes to negative gearing would likely cause property prices to fall or stagnate, and also do little to improve young people's access to the property market (Scarr and Hennessy 2019).

\section{Regional results}

It became apparent on election night that Labor's confidence of a resurgence in the State was misplaced. The gains achieved by Labor in 2016 almost evaporated in 2019. While the swing against the party's two-party-preferred vote was slim ( 0.9 per cent), its primary vote suffered a larger, 2.7 per cent swing against it, falling to 29.8 per cent-the second worst State-level performance for Labor.

Although federal Labor retained its five existing West Australian seats, the outcome suggests the malaise runs deep. The last time Labor attained seat parity with the Liberals in the State was in 1998 and the last time it held a plurality of West Australian electorates was in 1990. As Table 11.6 shows, the strongest swings recorded against Labor were in outer metropolitan 
electorates, followed by rural seats. Between them, these electorates constitute 10 of Western Australia's 16 seats. And while the average size of the swing against Labor in the inner metropolitan electorates was less severe, it comes off an already low base. In the inner metropolitan seats where the Greens averaged 14.3 per cent of the primary vote, the minor party entrenched its status as Labor's curse and saviour.

Table 11.6 West Australian election results by seat demographic

\begin{tabular}{|l|r|r|r|}
\hline & \multicolumn{1}{|c|}{$\begin{array}{c}\text { Inner } \\
\text { metropolitan }\end{array}$} & $\begin{array}{c}\text { Outer } \\
\text { metropolitan }\end{array}$ & Rural \\
\hline Liberal average first-preference vote & 45.03 & 41.47 & 46.27 \\
\hline Liberal average first-preference swing & -3.25 & -2.08 & 1.65 \\
\hline Labor average first-preference vote & 30.19 & 33.00 & 21.30 \\
\hline Labor average first-preference swing & -0.28 & -5.81 & -2.02 \\
\hline Greens average first-preference vote & 14.32 & 10.05 & 9.79 \\
\hline Greens average first-preference swing & -0.34 & -1.40 & -1.00 \\
\hline Other average first-preference vote & 10.12 & 15.46 & 22.55 \\
\hline Other average first-preference swing & 4.13 & 8.36 & 1.28 \\
\hline
\end{tabular}

Source: Author's calculation from AEC (2019b).

\section{South Australia}

\section{By Narelle Miragliotta}

One journalist lamented during the campaign that 'the arithmetic' did not favour South Australia in 2019 (Wills 2019b: 44). This assessment is difficult to disagree with entirely. South Australia has only ever returned a comparatively small number of federal lower house seats but, following the 2017-18 redistribution, its share of seats contracted further, from 11 to 10 (see further, Chapter 9, this volume). In the final analysis, only one seat was identified as vulnerable following the redistribution, the seat of Boothby, held by the Liberal incumbent, Nicolle Flint, on a margin of 2.7 per cent. Flint gained notoriety over her decision to sign the petition that led to the unseating of Malcolm Turnbull. This brought Flint unwanted attention, especially from GetUp!, which designated her one of the six 'hard right wreckers' that it campaigned against (Gailberger 2019a: 10). 
But with only one seat truly competitive, the federal leaders did not spend significant time campaigning in the State. Over the course of the campaign, the two leaders visited South Australia five times apiece; in comparison, they made 16 stops in total to Tasmania (see Table 11.1). This did not mean, however, that either party ignored the State or Boothby, where the combined major party pre-election spending commitments for the marginal seat totalled $\$ 400$ million (Wills 2019a: 6). Similarly, the Liberals - seeking to strengthen their prospects in Sturt, vacated by Christopher Pyne-committed $\$ 100$ million in funding for three road projects in that electorate (Blaxendale and Varga 2019: 6). Labor sought to distinguish its party by, among other things, pledging to commission an independent study into the potential impact of an oil spill in the Great Australian Bight (Gailberger 2019b: 6).

Further reducing the urgency for the major parties was the absence of the NXT and, more particularly, its leader and founder, Nick Xenophon. Although the NXT was rebadged as the Centre Alliance when Xenophon quit politics in 2018, the new party, in his absence, was a more muted force, fielding only three lower house and two Senate candidates.

Table 11.7 South Australian election results by seat demographic

\begin{tabular}{|l|r|r|r|}
\hline & \multicolumn{1}{|c|}{$\begin{array}{c}\text { Inner } \\
\text { metropolitan }\end{array}$} & $\begin{array}{c}\text { Outer } \\
\text { metropolitan }\end{array}$ & Rural \\
\hline Liberal average first-preference vote & 38.80 & 34.63 & 48.72 \\
\hline Liberal average first-preference swing & 5.21 & 4.68 & 7.29 \\
\hline Labor average first-preference vote & 40.95 & 44.64 & 19.16 \\
\hline Labor average first-preference swing & 4.03 & 6.40 & 0.63 \\
\hline Greens average first-preference vote & 11.70 & 9.22 & 6.90 \\
\hline Greens average first-preference swing & 4.27 & 3.45 & 2.08 \\
\hline Other average first-preference vote & 8.48 & 25.20 & 11.43 \\
\hline Other average first-preference swing & -12.54 & -15.35 & -10.36 \\
\hline
\end{tabular}

Source: Author's calculation from AEC (2019b).

The demise of the NXT, and the limited appeal of its successor, the Centre Alliance-despite holding on to the seat of Mayo, represented by Rebekha Sharkie - proved advantageous for the major parties. South Australia was the only jurisdiction where Labor (3.8 per cent) and the Liberals (5.7 per cent) both increased their Statewide share of the primary vote (see Table 11.7). And, while neither restored fully its pre-2016 firstpreference vote, nor did either lose any of its existing seats. 


\section{Tasmania}

\section{By Nick Economou}

Tasmania accounts for only five of the 151 seats in the House of Representatives, but it is very rare for national election campaigns not to focus on at least two of these seats. This reflects the reality that the two perennial battleground seats of Bass and Braddon, which cover the northeast and northwest of the State, are always marginal and consistently hold out the hope to the major party in Opposition that they can be won.

With the published national opinion polls fuelling expectations of a government-changing election, and given the recent by-election result in Braddon, Labor might have been confident of holding all four of its Tasmanian seats. Whatever Liberal Party strategists thought of the opinion polls, the government's strategy was clear enough: defence of government would require winning at least Braddon from Labor and possibly taking Bass as well. As it turned out, the Liberal strategy in Tasmania was successful. Labor was defeated in both Braddon and Bass. Tasmania was a significant failure for the Labor campaign while the effort put into campaigning in the north by Prime Minister Scott Morrison was rewarded with gains that allowed the government to increase its overall House of Representatives majority.

\section{Contextual factors}

In March 2018, a State election was held in which the incumbent Liberal Government was re-elected despite some expectations that Premier Will Hodgman (now retired) might struggle to win a lower house majority. Confusingly, having obtained a swing towards it and having increased its total seat share, Labor also appeared to have performed creditably in this contest. The problem with this, however, was that Labor gains had occurred at the expense of the Greens rather than the Liberals, andarguably of greater significance-there was a serious differential in Labor's performance in the northern divisions compared with those in the south.

\section{The campaign in Tasmania}

By the halfway point of the campaign, monitoring by the Australian Broadcasting Corporation (ABC) of the campaign visits conducted by Morrison and Bill Shorten noted how often Morrison had 
visited Tasmania and that Braddon was one of the most oft-visited seats in the Prime Minister's campaign travels (Doran et al. 2019). The Advocate - the newspaper published in Burnie and read across the Braddon electorate-was even more enlightening on how the major party campaigns were going. The paper noted (presumably with some disapproval) that not only had the Opposition leader been to the southern Tasmanian seats more often than to the north, he had also promised money for southern indulgences of which northerners disapproved, such as a commitment of more federal funding for the Hobart-based Museum of Old and New Art (MONA). And, if that was not bad enough, Shorten also promised to support Tasmania having a team in the Australian Football League (Bailey and Jarvie 2019). In so doing, he aligned himself (perhaps inadvertently) with those who were advocating that the Tasmanian team be based in Hobart - a cardinal error for a leader whose primary objective should have been to curry favour with interests in Launceston, Burnie and Devonport.

\section{Regional results}

The Statewide result was a curious mix of contrary swings, the only consistency of which lay in the sharp distinction in voting behaviour between the Tasmanian north (Bass and Braddon) and the south (Franklin and Clark). The north-south divide was also evident in the sprawling division of Lyons, where booths in centres in the north (Deloraine, Longford and Prospect) were won on the two-party-preferred vote by the (disendorsed) Liberal, while the two-party majority for Labor tended to get stronger the closer booths were to Hobart. Labor secured a large share of the Statewide two-party-preferred vote (55.9 per cent, down by 1.4 percentage points) but could win only two (that is, 40 per cent) of the five seats.

The regional swings give a better account of what happened. The two-partypreferred swing to the Liberals in Bass was 5.8 per cent and in Braddon, 4.8 per cent. On the other hand, the swing in Franklin was 1.5 per cent to Labor, making this one of the safest Labor divisions in the country, and in Lyons, the two-party-preferred swing of 1.3 per cent also went to Labor. Clark, meanwhile, firmed for the Independent Andrew Wilkie, with a swing of 4.3 per cent. The significance of these regional variations lay in the transfer of seats. With swings towards them, incumbents in Clark (Wilkie), Franklin and Lyons (both Labor seats) were re-elected. Bass and 
Braddon, however, changed, with the Liberal candidates, Brigit Archer and Gavin Pearce, winning their respective seats from Labor incumbents. This was precisely the outcome the Liberals' national strategy had been geared to achieve and, as such, the importance of the Tasmanian result lay in its contribution to the return of the Morrison Government with a majority.

It is difficult to interpret the deeper meaning of the Tasmanian contribution to the 2019 election. At one level, the result conforms to a longstanding pattern in which Labor wins the Statewide two-party vote but does not win all, or many, of the five available seats. Denison/Clark appears to be the preserve of Wilkie, and Tasmania's most notoriously volatile electorates, Bass and Braddon, defied the Statewide result by being won by the Liberal Party, as they have been known to do in the past. Tasmania's regionalism was particularly noticeable in this election. The south of the State continued to be the electoral base for the social-democratic parties, including Labor and the Greens. On this occasion, the north of the State swung to the Liberals and, in the case of the northwest coast, embraced the populism of a candidate such as Jacqui Lambie.

\section{The Australian Capital Territory}

\section{By John Warhurst}

There were two distinctive aspects to the ACT campaigns. The first were local ACT issues. These included the funding of national institutions, including the National Gallery of Australia, National Library of Australia, National Museum and the Australian War Memorial. In the case of the first three and others, the issue was too little government funding, while in the case of the War Memorial, it was criticism of the overly generous $\$ 500$ million funding of an expansion plan developed by its DirectorGeneral, Dr Brendan Nelson, a former Liberal Opposition leader (Zhou 2019).

Funding of the Australian Public Service and other public service matters are always an issue in the Australian Capital Territory, and this was so again. Labor campaigned on a better deal for the public service, including reducing spending on private consultants. Late in the campaigncontroversially, after most pre-poll voting had finished-the government announced cuts of $\$ 1.5$ billion over four years to the public service to fund its election campaign spending promises (Whyte 2019a). 
The second unique aspect was the energetic campaign against conservative Liberal Senator Zed Seselja (Warhurst 2019). He has long been a controversial figure in the Australian Capital Territory among the factionalised Liberal Party and within the Canberra community. He opposed same-sex marriage during the postal survey and abstained from voting on the legislation during 2017. He was also one of the leading young guns supporting Peter Dutton's campaign against Malcolm Turnbull in 2018-both matters way out of character for left-leaning, socially progressive Canberra.

While the two major party senators are almost impossible to shift in Canberra-despite repeated efforts by the Democrats and the Greens, among others-this time the campaign was vociferous. Both the Greens candidate, Penny Kyburz, and Independent Anthony Pesec campaigned hard and they were joined by Unions ACT and Get Up!. Unions ACT ran an allegedly $\$ 100,000$ Dump Zed campaign (www.dumpzed.org.au [site discontinued]), including leaflets and a polling place presence. Its leaflet linked Seselja, Dutton and Tony Abbott. As voters queued to vote, they were handed empty scratchie cards with the messages 'Under Zed you will get Zilch' and 'Put Zed last. That's where he puts you'. Get Up! distributed how-to-vote cards urging: 'Vote for Climate Change. This time Don't Vote Liberal.' They urged a vote for Kyburz and Pesec because they offered 'very strong support for climate action'. By contrast, Katy Gallagher for Labor was rated a more muted 'Moderate Support for Climate Change' (though the how-to-vote card scarcely distinguished between the three candidates). For his part, Seselja relished the challenge and did not hide behind the Liberal brand. His campaign was personalised as 'Your local candidate for the Senate', using his distinctive brand name 'Zed' on the T-shirts of his many young volunteers.

\section{Regional results}

Labor won all three seats easily, but these seats are now more distinguishable in their voting patterns. Labor held its two-party-preferred position in the House of Representatives, despite suffering small negative swings in the southern seat of Bean, where the Independent environmentalist Jamie Christie polled 8.9 per cent and the Greens polled 13.7 per cent (more than 22 per cent in total), and in the northern seat of Fenner. In the central seat of Canberra, new Labor MP Alicia Payne won a two-partypreferred swing of 4 per cent and Tim Hollo (Greens) earned a swing of 
4.6 per cent up to 23.7 per cent, making it one of the nation's most Green electorates. In the Senate, Labor and the Liberals split the two seats, but there was a tiny swing against Seselja and a swing towards both the Greens (3.5 per cent, up to 19.4 per cent) and Independent Pesec (5 per cent). This means the anti-Zed campaign was ultimately ineffective, and he won close to a quota in his own right. According to Seselja, that showed that the 'personalised' campaign against him did not work. In reality, he was also protected by the two-seat system, as was always going to be the case.

Canberra remains a 'Labor town' with a strong green tinge (Whyte 2019b). That is also the case at the Territory level. Zed Seselja floats in a sea of red. To some, including former public service commissioner John Lloyd of the Institute of Public Affairs, this pattern is a worrying anomaly with possible implications for the connection between the Australian Public Service and the wider community (Dingwall 2019). The largely conservative ideological character of the ACT Liberals is something of an enigma; moderation might be suggested by the demographics if greater electoral success is desired. Any change in ACT representation in future elections remains highly unlikely.

\section{The Northern Territory}

\section{By Will Sanders}

At the 2016 federal election, support for the Country Liberals was at a historic low and the two-term Country Liberal Member of the House of Representatives for the Darwin-based seat of Solomon, Natasha Griggs, lost her seat comprehensively with just 34.5 per cent of first-preference votes and 44 per cent of the two-candidate-preferred count. This probably reflected the disarray of the Country Liberal Government in the Northern Territory Legislative Assembly, which had suffered both a change of chief minister and several defections since its election in August 2012 (Smee and Walsh 2016). A month after Griggs's loss, the Country Liberals under Adam Giles lost the August 2016 Legislative Assembly election to Labor under Michael Gunner in a similarly comprehensive fashion.

During the 2019 election campaign, the Northern Territory achieved prominence in the national media just once, when Prime Minister Scott Morrison and Opposition leader Bill Shorten both visited, on Tuesday, 23 April. As well as supporting the Country Liberals' two aspiring women candidates for the House of Representatives and a new woman Senate 
candidate, Morrison criticised the Gunner Territory Labor Government, which by the end of 2018 was suffering defections over management of its large debt and Budget deficit. Morrison called Gunner's government the 'worst in the country' and argued that 'if you can't manage money, you can't run a country'. The not-so-hidden implication was that poor money management was a problem for Labor, which also extended to Shorten and his federal team. Shorten's task during his Territory visit was the more staid one of supporting two incumbent members of the House of Representatives and a senator seeking re-election. His rhetoric was about 'Territorians looking to the future' and 'taking opportunities', as 'Territorians do'.

When Labor retained its two Northern Territory House of Representatives seats in the 2019 election, this was interpreted by the party faithful in the Territory as a vote of confidence in the Gunner Government and as evidence that Morrison's criticisms of it had misfired (Gibson 2019). While this probably overinterprets the result, the 2016 story above suggests that legislative assembly elections and Commonwealth parliamentary elections in the Territory can interact.

From a larger geographic perspective in 2019, the obvious question is: why was the Northern Territory strong for Labor when Queensland to the east and Western Australia to west were so much more problematic? The political economies of these outlying regions based on resource extraction industries may seem rather similar, but there is something different occurring in the Territory electorally compared with Queensland and Western Australia. One difference is that the Territory, with its much smaller capital city in the north rather than the south, has a larger proportion of public administrators and other white-collar professionals building careers in the jurisdiction but ultimately destined to leave. Gerritsen (2010: 32-33) has called this 'the politics of the expatriates' and notes as a corollary that the 'real Territorians' are the Aboriginal people for whom the Northern Territory is a long-term home. This points to a second big difference from Queensland and Western Australia: the Indigenous proportion of the population in the Northern Territory.

With more than 40 per cent of its population identifying as Aboriginal and/or Torres Strait Islander in the 2016 census, the Northern Territory's second outback seat of Lingiari stands out as the one House of Representatives division in which Indigenous Australians are a high enough proportion of the population to have significant electoral power. 
The Country Liberals' 2019 pre-selection in Lingiari of prominent young Warlpiri woman and Alice Springs town councillor Jacinta Price suggested an attempt to attract Aboriginal votes. While her primary vote was 5 per cent higher than her predecessor's in 2016, the Labor vote for the incumbent, Warren Snowdon, was also up 5 per cent. Whereas in 2016 there had been nine candidates in Lingiari (including one prominent Yolngu Independent, who attracted 4.3 per cent of votes), in 2019, there were just six candidates to share the primary vote. While Price was the prominent Indigenous candidate in 2019, her vote was strongest in the regional towns and weaker in the discrete Aboriginal communities. Snowdon, by contrast, won these discrete communities serviced by remote-area mobile polling even more convincingly than in past elections when he had also faced high-profile Aboriginal candidates.

Snowdon's seven-term tenure in Lingiari suggests that the Aboriginality of candidates has made little difference to recent Commonwealth parliamentary elections in the Northern Territory. No doubt, in this one House of Representatives division in which there is such a significant Aboriginal presence, Labor will think hard about an Aboriginal replacement candidate for Snowdon. But in the meantime, Aboriginal voters have not moved in large numbers to support Aboriginal candidates, whether as Independents, for the Country Liberals, for general minor parties or, as in 2013, for Australia's First Nations Political Party.

Since 2010, the AEC has invested significantly in Indigenous electoral participation. In 2019, the AEC produced a table (Table 11.8) as part of its work on enrolment. In the 151 divisions of the House of Representatives grouped in Table 11.8, the two outlying divisions with an 'enrolment rate' compared with the 'estimated enrolment eligible population' in the range $75-80$ per cent are Lingiari and Durack, in the Kimberley region of Western Australia. These are also the two divisions with the highest proportions of Indigenous people in their populations. Turnout against enrolment is also a problem in Lingiari, which is the one House of Representatives division in the far-right column of Table 11.9-two categories lower in turnout than any other. Increased enrolment among Aboriginal people in Lingiari could, ironically, decrease turnout further, unless the AEC can also improve Indigenous participation in remote-area mobile polling. 
Table 11.8 Enrolment in 151 House of Representatives divisions compared with 'Estimated enrolment eligible population', March 2019

\begin{tabular}{|c|c|c|c|c|c|c|}
\hline & $>98 \%$ & $\begin{array}{l}>95 \% \\
<98 \%\end{array}$ & $\begin{array}{l}>90 \% \\
<95 \%\end{array}$ & $\begin{array}{l}>85 \% \\
<90 \%\end{array}$ & $\begin{array}{l}>80 \% \\
<85 \%\end{array}$ & $\begin{array}{l}>75 \% \\
<80 \% \\
\end{array}$ \\
\hline No. of HoR divisions & 54 & 52 & 41 & 1 & 1 & 2 \\
\hline
\end{tabular}

Source: Australian Electoral Commission, enrolment statistics.

Table 11.9 Votes cast against enrolment in 151 House of Representatives divisions, July 2019

\begin{tabular}{|c|c|c|c|c|c|c|}
\hline & $>95 \%$ & $\begin{array}{l}>90 \% \\
<95 \%\end{array}$ & $\begin{array}{l}>85 \% \\
<90 \%\end{array}$ & $\begin{array}{l}>80 \% \\
<85 \%\end{array}$ & $\begin{array}{l}>75 \% \\
<80 \%\end{array}$ & $\begin{array}{l}>70 \% \\
<75 \%\end{array}$ \\
\hline No of HoR divisions & 1 & 126 & 21 & 2 & 0 & 1 \\
\hline
\end{tabular}

Source: Australian Electoral Commission, 2019 Australian federal election results.

Aboriginal electoral power in remote areas of the Northern Territory is real, by virtue of population proportions, and probably explains the different results in the Territory in 2019 compared with remote areas of Queensland and Western Australia. However, enrolment and turnout figures suggest that such Aboriginal electoral power may still have considerable untapped potential.

\section{References}

Australian Bureau of Statistics (ABS). 2018. Australian National Accounts: State Accounts, 2017-18. Cat. no. 5220.0 Canberra: ABS. www.abs.gov.au/AUS STATS/abs@.nsf/DetailsPage/5220.02017-18?OpenDocument.

Australian Electoral Commission (AEC). 2019a. 'House of Representatives: First preferences by party-Qld'. Tally Room 2019 Federal Election. Canberra: AEC. results.aec.gov.au/24310/Website/HouseStateFirstPrefsBy Party-24310-QLD.htm.

Australian Electoral Commission (AEC). 2019b. 'House of Representatives: First preferences by party'. Tally Room 2019 Federal Election. Canberra: AEC. results.aec.gov.au/24310/Website/HouseStateFirstPrefsByParty-24310-NAT. htm.

Australian Labor Party (ALP). 2019a. Labor's Fair Plan for Schools. Sydney: ALP. www.fairgoforschools.com.au/. 
Australian Labor Party (ALP). 2019b. Nation-Building Infrastructure. Sydney: ALP. www.alp.org.au/media/1902/nation_building_infrastructure. pdf [page removed].

Bailey, Sue and Emily Jarvie. 2019. 'Week 3 of the 2019 federal election campaign: Analysis'. The Advocate, [Burnie], 5 May. www.theadvocate.com.au/ story/6106681/candidate-headaches-dog-parties/.

Blaxendale, Rachel and Remy Varga. 2019. 'Marginal motive in transport spending'. The Australian, 4 April: 6.

Brown, Greg. 2019. 'Shorten yet to rule out Adani review'. The Australian, 23 April: 5.

Chan, Gabrielle. 2019. 'Shorten evokes Whitlam the hero, but is it really going to be his time?'. The Guardian, 16 May.

Charlton, Peter. 1983. State of Mind: Why Queensland is Different. Sydney: Methuen-Haynes.

Commins, Patrick. 2019. 'Per capita recession looms again'. Sydney Morning Herald, 4 March: 23.

Dingwall, Doug. 2019. 'Agencies should consider relocating jobs'. The Canberra Times, 4 June.

Doran, Matthew, Andrew Kesper and Emma Machan. 2019. 'Halfway to the election, where have the leaders been?'. ABC News, 1 May. www.abc.net.au/ news/2019-05-01/federal-election-campaign-heatmap-shows-where-leadersvisiting/11059550.

Fiorina, Morris. 1981. Retrospective Voting in American Elections. New Haven, CT: Yale University Press.

Gailberger, Jade. 2019a. 'Boothby battle begins'. The Advertiser, [Adelaide], 9 April: 10.

Gailberger, Jade. 2019b. 'Labor makes waves in Bight'. The Advertiser, [Adelaide], 9 April: 6.

Gerritsen, Rolf. ed. 2010. North Australian Political Economy: Issues and Agendas. Darwin: Charles Darwin University Press.

Gibson, Jano. 2019. 'Northern Territory Labor optimistic of 2020 re-election after federal election results'. ABC News, 20 May. www.abc.net.au/news/ 2019-05-20/election-results-give-nt-labor-optimism-for-re-election-in-2020/ 11131530. 
Hanrahan, Catherine. 2019. 'Vote Compass finds voters are split on economy and environment as most important issue'. $A B C$ News, 17 April. www.abc.net.au/ news/2019-04-17/vote-compass-election-most-important-issues/11003192.

Hewett, Jennifer. 2019. 'A highly taxing campaign for voters'. Australian Financial Review, 15 April: 2.

Hondros, Nathan, Hamish Hastie and Hannah Barry. 2019. 'WA budget inches back into surplus but debt will have to wait a while'. WAtoday, 9 May. www. watoday.com.au/national/western-australia/wa-budget-inches-back-intosurplus-but-debt-will-have-to-wait-a-while-20190509-p51lq5.html.

Killoran, Matthew. 2019. 'Backing for coal despite activists'. The Courier-Mail, [Brisbane], 20 April: 17.

Killoran, Matthew and Annika Smethurst. 2019. 'Big tax win for Morrison'. The Courier-Mail, [Brisbane], 12 May: 11.

Laschon, Eliza. 2018. 'The GST overhaul has been given the green light: Here's what it all means for WA'. ABC News, 14 November. www.abc.net.au/news/ 2018-11-14/gst-explainer-how-will-wa-spend-its-windfall/10493500.

Lewis, R. 2019. 'Labor leaders building bridges in the west'. The Australian, 16 May: 9.

Liberal Party of Australia. 2019a. Election Policies. Canberra: Liberal Party of Australia. www.liberal.org.au/our-policies.

Liberal Party of Australia. 2019b. Our Plan for Western Sydney. Canberra: Liberal Party of Australia. www.liberal.org.au/our-plan-western-sydney.

McKay, Jack. 2019. 'Coal shoulder a sign of the times'. The Courier-Mail, [Brisbane], 24 April: 12.

McQueen, Humphrey. 1979. 'States of the Nation: Queensland-A State of Mind'. Meanjin 38: 41-51.

Marszalek, Jessica. 2017. 'Greens take it to Trad'. The Courier-Mail, [Brisbane], 26 November: 7.

Martinez i Coma, Ferran and Rodney Smith. 2018. 'The States and Territories'. In Double Disillusion: The 2016 Australian Federal Election, edited by Anika Gauja, Peter Chen, Jennifer Curtin and Juliet Pietsch, 211-34. Canberra: ANU Press. doi.org/10.22459/DD.04.2018.09.

Murphy, Denis. 1978. 'Queensland's Image and Australian Nationalism'. Australian Quarterly 50: 77-91. 
New South Wales (NSW). 2018. Budget Statement 2018-2019. Budget Paper No. 1. Circulated by The Hon. Dominic Perrottet MP, Treasurer, and Minister for Industrial Relations. Sydney: NSW Government. www.budget.nsw.gov. au/sites/default/files/budget-2018-06/Budget_Paper_1-Budget_Statement_ UDPATED_2.pdf.

Queensland Government Statistician's Office (QGSO). 2019. Employment Growth and Unemployment, Queensland and Australia, 1978-79 to 2017-18. Brisbane: Queensland Treasury.

Scarr, Lanai. 2019a. 'Federal election 2019: Scott Morrison would call Perth home if he didn't live in Sydney'. West Australian, [Perth], 26 April. www.thewest. com.au/politics/federal-election-2019/federal-election-2019-scott-morrisonwould-call-perth-home-if-he-didnt-live-in-sydney-ng-b881179309z.

Scarr, Lanai. 2019b. 'The west could be the key in the fight for power'. West Australian, [Perth], 13 May. www.thewest.com.au/opinion/lanai-scarr/lanaiscarr-the-west-could-be-key-in-fight-for-power-ng-b881196453z.

Scarr, Lanai and Annabel Hennessy. 2019. 'Federal election 2019: Negative gearing changes may hit Labor heartland'. West Australian, [Perth], 8 May. www.thewest.com.au/politics/federal-election-2019/federal-election-2019negative-gearing-changes-may-hit-labor-heartland-ng-b881184514z.

Smee, Ben and Christopher Walsh. 2016. Crocs in the Cabinet: Northern Territory Politics-An Instruction Manual on How Not to Run a Government. Sydney: Hachette Australia.

Viellaris, Renee. 2019. 'A little ray of sunshine'. The Courier-Mail, [Brisbane], 18 May: 6.

Warhurst, John. 2019. 'Canberra and the Zed phenomenon'. The Canberra Times, 23 May.

Whyte, Sally. 2019a. 'Coalition's \$1.5b cut from public service'. The Canberra Times, 17 May.

Whyte, Sally. 2019b. 'Election 2019: How successful were the effort of Independents and the Greens in Canberra?'. The Canberra Times, 19 May.

Williams, Paul D. 2009. 'Leaders and Political Culture: The Development of the Queensland Premiership, 1859-2009'. Queensland Review 16(1): 15-34.

Williams, Paul D. 2011. 'How Did They Do It? Explaining Queensland Labor's Second Electoral Hegemony'. Queensland Review 18(2): 112-33. 
Williams, Paul D. 2018a. 'Back from the Brink: Labor's Re-Election at the 2017 Queensland State Election'. Queensland Review 25(1): 6-26.

Williams, Paul D. 2018b. 'One, Two or Many Queenslands? Disaggregating the Regional Vote at the 2017 Queensland State Election'. Australasian Parliamentary Review 33(2): 57-79.

Wills, Daniel. 2019a. 'To the victor, the spoils in road funding splash'. The Advertiser, [Adelaide], 3 April: 6.

Wills, Daniel. 2019b. 'Why arithmetic does not add up for South Aussies'. The Advertiser, [Adelaide], 11 May: 44.

Worthington, Brett. 2019. 'Federal election 2019: Leaders channel Whitlam as they make their final pitches to voters'. $A B C$ News, 17 May. www.abc.net.au/ news/2019-05-16/federal-election-day-35-shorten-morrison-whitlam-rwanda/ 11119682.

Zhou, N. 2019. 'War Memorial expansion's opponents say $\$ 500$ million better spent on veterans'. The Guardian, 23 March. 
This text is taken from Morrison's Miracle: The 2019 Australian Federal Election, edited by Anika Gauja, Marian Sawer and Marian Simms, published 2020 by ANU Press, The Australian National University, Canberra, Australia.

doi.org/10.22459/MM.2020.11 